\title{
The Modalities of Students' Engagement in Tunisian Private School
}

\author{
Nabila Bennour 1,2 \\ ${ }^{1}$ University of Gafsa, Gafsa, Tunisia \\ ${ }^{2}$ UMR (EFTS), Toulouse, France \\ Email: nabilabennour2007@yahoo.fr
}

Received 24 April 2015; accepted 21 May 2015; published 26 May 2015

Copyright (c) 2015 by author and Scientific Research Publishing Inc.

This work is licensed under the Creative Commons Attribution International License (CC BY). http://creativecommons.org/licenses/by/4.0/

(c) (i) Open Access

\begin{abstract}
In this article, we describe a particular aspect of the teaching-learning process: students' cooperation. Our research attempts to understand the modalities of student engagement at a private institution in Tunisia. We mobilize the theoretical framework of the ecology of physical education (Tousignant, 1982) as a framework for this research. The data results from video recording and ethnographic observations of a gymnastics cycle conducted by a teacher specialist of tennis. The study was conducted according to a macroscopic analysis of students' behavior of cooperation during three sessions of school education of gymnastics. Through the comparison of forms of engagement for contrasted students (high vs. low), the results reveal recurring characteristics and differences in degrees of cooperation between students according to their school levels.
\end{abstract}

\section{Keywords}

Ecology of Physical Education, Engagement, Gymnastics

\section{Introduction}

The researchers developed in the context of motor learning and in context of sport pedagogy raise the importance of engagement of physical education student in the teaching/learning process.

Therefore, these researches point the need to better understand the modalities of students' engagement in physical education classes. In reality, however, physical education teachers make recurrent observations of students who do not progress in class. In this regard, Tunisians teachers express their difficulties in obtaining learning with students. They emphasize their low participation in class and point differences in the duration of engagement between students according to their skill levels, their motivations, their interests, etc. These findings in the literature (Carlier, 2004; Doyle, 1986; Siedentop, 1994) show that all students do not engage in the same way in the proposed tasks. 
Researchers in didactics for their part showed that according to their school position (high, medium, or low) students are solicited by their teacher differentially (Schubauer-Leoni, 1996; Elandoulsi, 2011).

So in light of the recurring difficulties raised by the Tunisian physical education teachers about the non-engagement of their students, their non-participation in class; in relation to the difficulties they have to obtain significant changes in motor learning, our research problematic is to describe student engagement in teaching gymnastics in Tunisia. In a private institution and through the comparison of modalities of student engagement, we seek to identify how students participate in class? And if students of different school positions (high vs. low) participate in the same way in the tasks proposed by the teacher?

\section{Theoretical Registration}

In the 1980s, the North American paradigm of the classroom ecology allowed a better understanding of the class activity in all its complexity. This paradigm is to "study the relations between the requests of the environment, that is to say, classroom situations, and how people are responding” (Doyle, 1986).

According to this research streams, the researcher attempts to enter in more depth in the world of the classroom in order to understand the sense and the meanings that teachers and students give it in order to perform its description while taking place in a global perspective. The proponents of this paradigm stipulate that the data collected by ethnographic observation allow new hypotheses to discover patterns which could be important for the life of the class.

In physical education, the ecological model was applied by Tousignant and Siedentop (1983). "The ecology of physical education" is a research stream of which has been the subject of many studies in our discipline (Siedentop, 1994; Musard, Latch and Carlier, 2010). The first research on the issue of student participation in physical education class (Tousignant, 1982) reported their engagement by considering the context of learning action. To understand the dynamics of the ecological balance of the physical education class, the author was interested in how students participated in the course in terms of cooperation.

Tousignant (1985) considers the cooperation of students in the learning tasks assigned to them as a precondition for any learning these same tasks. In a qualitative study she describes four categories of student behavior when they realize the tasks required of them: complete cooperation, the circumstantial cooperation, disguised non-cooperation, expressed non-cooperation. These categories, revealing the degree of cooperation of the students are defined as follows:

- Behaviors of application: the author presumes that when students realize the task, as it was dictated by the teacher, they are qualified as "applied". Students are attentive, they participate in the management of the activity and they engage in learning tasks. These behaviors are an indicative of complete cooperation.

- Tasks transformation behaviors: the author highlighted the fact that when students are confronted with a task that does not correspond to their skill level, they make changes to the task. They can change the rules of a game or improvise new ways to exercise and even change the nature of the task. These behaviors are associated with a circumstantial cooperation.

- Evasive behavior: the author specifies that these behaviors match those of students who "hide their non-cooperation in just evading the achievement of tasks so that teachers think they realize the assigned task" (Tousignant, 1985). These evasive behaviors which do not really disturb the progress of the class are indicators of a disguised non-cooperation.

- Deviant behaviors: the author describes a deviant behavior when a student refuses completely to cooperate. This category includes classics deviance such as talk or fights with a friend during the session and also modifies the task unacceptably. These incompatible behaviors with the objectives set by the teacher obviously disrupt the progress of the class and inhibit learning. Deviant behaviors are connected to an expressed non-cooperation.

The theoretical framework of the model of the classroom ecology of physical education is extremely relevant to look at the level of student engagement in different systems tasks that the teacher offered. Researches in the classroom ecology are more interested in student engagement in terms of classroom climate, educational relationships or ecological balance than in terms of participation in academic achievement.

\section{Methods}

Our research reports a case study in a private school, which aims to observe the modalities of student engage- 
ment in the teaching/learning process. As we stand in an ethnographic approach, the search follows a descriptive approach.

\subsection{Characteristics of the Observed Empirical Contexts}

\subsubsection{Context of the Institution}

The International School of Carthage (ISC) is a Tunisian private high school. With international vocation, the school is approved by the French Ministry of National Education. Located in Carthage, in the district of Tunis, it is distinguished by modern architecture interspersed with green areas creating a quality of life as we find in Europe. The ISC prepares students for the Diploma and the French Brevet exams in general bachelor (Series: scientific (S), economic and social (ES)).

The ISC is an establishment with a team of 6 teachers of physical education relatively stable for five years. It is constituted by three women and three men. The organization of the physical education is based on French programs. In bachelor's degree students choose three activities of a menu, on which they will be evaluated.

\subsubsection{Context of the Learning Cycle and the Observed Sessions}

The learning cycles from which are extracted the three sessions analyzed is a cycle of eight sessions of two hours planned for the last semester of the school year just after spring holidays. It takes place with bachelor's science class (S1 and S2) and Economic and Social class (ES).

Three sessions were observed with each time an interview ante and post session. An interview ante observation was made in the beginning of the second semester cycle and an interview post observation was completed at the end of the cycle before the baccalaureate exam.

\subsubsection{Characteristics of the Teacher}

The teacher that we named Sonia pursued her higher education at the High Institute of Sport and Physical Education of Ksar Said (Tunisia) for four years. She holds a Master in Science and technology of physical activities and sports. She has always been a teacher in public schools before integrating the private education, four years ago at the ISC.

Sonia has twenty-two years of experience as a teacher of physical education and has always taught gymnastics for terminals classes. She has tennis as a specialty.

\subsubsection{Classroom Characteristics and Choice of Selected Students}

The class group is composed of three terminal classes: ES (12 students), S1 (4 students) and S2 (6 students). The class has 22 students including 6 exempted students. 16 girl students are expected to be present during the learning cycle.

According the methodological principle, it is the teacher who indicated the four students ("strong" and "weak") retained for research (Leutenegger, 2003). These students have the following characteristics as shown in Table 1.

\subsection{Data Collection}

We collected data concerning students' activity and teachers' activity in ordinary class. We filmed three consecutive sessions of learning aims in a gymnastics cycle in private institution in connection with the preparation of baccalaureate exam in physical education according to the French programs.

Table 1. Characteristics of students selected for the research.

\begin{tabular}{|c|c|c|c|c|}
\hline \multirow{2}{*}{ Names } & \multirow{2}{*}{ Codes } & \multirow{2}{*}{ Skill levels } & \multicolumn{2}{|c|}{ Parents’ socio-economic levels } \\
\hline & & & Mothers & Fathers \\
\hline Myriam & F14 & Strong & Engineer & Accounting officer \\
\hline Farah & $\mathrm{F} 21$ & Strong & Teacher & University professor \\
\hline Amani & $\mathrm{f} 2$ & Weak & Jobless & Manager to the bank \\
\hline Sarra & f7 & Weak & Official in a travel agency & Architect \\
\hline
\end{tabular}


For the three filmed and observed sessions, we identified the planning of the teacher to learn about the objects taught and we also took notes to look after the tasks proposed to students, the action of the teacher in the presentation of the work. We took notes on motor actions of students and their evolutions during the session, on the relations with peers, and during discussions with the teacher during or after the action.

We particularly noted impressions on the class and/or on the teacher, on the elements on the content taught, on unexpected incidents and on the general functioning of the class (Amade-Escot \& Marsenach, 1995). For example, we took notes on the devices, the methods of organization, the types and the degree of difficulty of the proposed situations.

We noted, also, the way in which the teacher presented and regulated them. We also took into consideration the participation and engagement of students in the proposed tasks. The movie of the session was doubled by simultaneous notes which allow the didactic script (Amade-Escot \& Léziart, 1996).

\subsection{Processing and Data Analysis}

The processing and the data analysis are based on the framework of the classroom ecology description. The analysis allows the understanding of the engagement of students in the teaching/learning process.

A behavior chronic interested in the engagement of four students selected in situation of teaching/learning in gymnastics. This is to study the engagement of two "strong" students and two low "students" following the ecological approach based on the degree of cooperation (Tousignant, 1985). Abbreviations of these behaviors are used in the following manner to facilitate their reading from table:

- AB for application behavior;

- TTB for task transformation behavior;

- EB for evasive behavior;

- and DB for deviant behavior.

On a double entry table, the chronic presents temporal dimensions of the engagement of four students selected for the study. Horizontally, the table presents the various successive tasks of each session indicating the overall time spent on this task. On the vertical axis, are presented the behavior of student engagement using a sequential method of observation every fifteen seconds. Are listed vertically application, transformation task, evasive or deviant behavior as students act in this task.

Chronic ran as follows as shown in Table 2.

The analysis allows us to have a global apprehension of the degree of the engagement of the four students observed as well as an estimation of the frequency of the different behaviors during the session.

\section{Results and Discussion}

The three observed sessions answer three different objectives. They are characterized by a duration, a number of students and very different number of tasks. This variability is summarized in Table 3.

When we use the categories of the classroom ecology in physical education, we note in this private institution and during the three observed sessions that:

- Students apply in tasks prescribed by the teacher. We record more important percentages of behavior of application than the other categories during the three sessions reflecting a predominance of a complete cooperation.

- The degree of cooperation of F14, F21 and f2 does not seem affected by their level skill. For example, the student $\mathrm{f} 2$ of low school position engages in the activity as frequently as the students F14 and F21 and even more as it is the case in session 2.

- A significant gap is recorded between both students f2 and f7 who present different duration of behavior of application. The student f7 present an important duration of evasive and deviant behaviors (nearly $18 \mathrm{mi}-$ nutes in session 1). This reflects a non-cooperation with this student, who oscillate between an expressed non-cooperation and a disguised non-cooperation.

- The pupils whatever is their school position are able to produce tasks transformation behavior.

- Finally, the duration of task transformation behavior of F14 and F21, students in high school position is more important than students in low school position.

The results in terms of percentages relative to the degrees of cooperation of the four students observed during the sessions, are illustrated in Table 4 . 
Table 2. Behavior chronic extract of strong and weak students following the degree of cooperation of Tousignant (1985). Task 1 , session 2 .

\begin{tabular}{|c|c|c|c|c|c|}
\hline \multirow{3}{*}{ Time } & \multicolumn{5}{|c|}{ Task1 15'01" } \\
\hline & Students & F14 & F21 & $\mathrm{f} 2$ & f7 \\
\hline & Duration & \multicolumn{4}{|c|}{ Behavior } \\
\hline \multicolumn{6}{|l|}{$15^{\prime}$} \\
\hline & $15^{\prime \prime}$ & $\mathrm{AB}$ & $\mathrm{AB}$ & $\mathrm{AB}$ & $\mathrm{AB}$ \\
\hline & $30^{\prime \prime}$ & $\mathrm{AB}$ & $\mathrm{AB}$ & $\mathrm{AB}$ & $\mathrm{AB}$ \\
\hline & $45^{\prime \prime}$ & $\mathrm{AB}$ & $\mathrm{AB}$ & $\mathrm{AB}$ & EB \\
\hline \multirow[t]{4}{*}{16} & $1 \mathrm{~min}$ & $\mathrm{DB}$ & $\mathrm{DB}$ & DB & $\mathrm{DB}$ \\
\hline & 1'15" & $\mathrm{AB}$ & TTB & $\mathrm{AB}$ & $\mathrm{DB}$ \\
\hline & 1'30" & EB & EB & EB & EB \\
\hline & $1^{\prime} 45^{\prime \prime}$ & DB & $\mathrm{AB}$ & $\mathrm{CE}$ & $\mathrm{DB}$ \\
\hline \multirow[t]{4}{*}{$17^{\prime}$} & $2 \min$ & $\mathrm{DB}$ & DB & DB & $\mathrm{DB}$ \\
\hline & 2'15" & DB & TTB & DB & $\mathrm{DB}$ \\
\hline & 2'30" & DB & TTB & DB & DB \\
\hline & $2^{\prime} 45^{\prime \prime}$ & $\mathrm{DB}$ & ТТВ & DB & $\mathrm{DB}$ \\
\hline \multirow[t]{4}{*}{18} & $3 \mathrm{~min}$ & $\mathrm{DB}$ & DB & DB & $\mathrm{DB}$ \\
\hline & 3'15" & DB & DB & DB & $\mathrm{DB}$ \\
\hline & 3'30" & EB & TTB & $\mathrm{AB}$ & ТTВ \\
\hline & 3'45" & ТТВ & ТTВ & $\mathrm{CA}$ & EB \\
\hline \multirow[t]{3}{*}{$19^{\prime}$} & $4 \min$ & DB & DB & DB & $\mathrm{DB}$ \\
\hline & 4'15" & $\mathrm{EB}$ & EB & $\mathrm{AB}$ & EB \\
\hline & 4'30" & 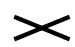 & $\infty$ & 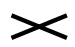 & 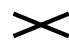 \\
\hline
\end{tabular}

Table 3. Context of the observed sessions.

\begin{tabular}{|c|c|c|c|c|c|}
\hline & $\begin{array}{l}\text { Present } \\
\text { students }\end{array}$ & $\begin{array}{l}\text { Session } \\
\text { duration }\end{array}$ & Session objectives & $\begin{array}{c}\text { Tasks’ } \\
\text { number }\end{array}$ & $\begin{array}{c}\text { Tasks’ } \\
\text { duration }\end{array}$ \\
\hline Session 1 & 9 & $60 ' 15^{\prime \prime}$ & $\begin{array}{l}\text { "The goal ... is the consolidation of gains/I am going } \\
\text { to work the element/... it is 8-3C/and this is the roll } \\
\text { backward piked/so I'll try to make progress.” }\end{array}$ & 7 & $47 ' 25 "$ \\
\hline Session 2 & 11 & $45^{\prime} 53^{\prime \prime}$ & "This is a review of the forward and backward roll" & 7 & $29 ' 75^{\prime \prime}$ \\
\hline Session 3 & 14 & 59'30" & $\begin{array}{l}\text { "It's a finalization ... we will carry out a small review } \\
\text { of all rolls and jumps and then we will do an } \\
\text { individual update for each student for the final step. }\end{array}$ & 10 & $50 ' 25 "$ \\
\hline
\end{tabular}

It appears from these findings that students’ engagement in learning tasks depends on modes of organization of the class and on teacher's ability to regulate the motor productions of students.

The observation shows that all sessions take place without differentiation of tasks. With the same content, students receive a direct instruction (Altet, Bressoux, Bru, \& Leconte-Lambert, 1996).

The organization of the class as a single group can deliver a maximum of information to many students in a synchronous way. In this form of organization, all students are considered as equals. The teaching is based on the implementation of standards activities. In this type of organization, the teacher assumes the responsibility of learning contents that is the same for all students.

From the didactic point of view we speak in this case of "topos surplombant" (Schubauer-Leoni, 2008). The priority is given to the relation teacher/knowledge as well as the class group. The student, as individuality is un- 
Table 4. Quantitative data of the behavior of four students during three sessions.

\begin{tabular}{|c|c|c|c|c|c|c|c|c|c|c|c|c|c|}
\hline \multirow{3}{*}{\multicolumn{2}{|c|}{$\begin{array}{c}\begin{array}{c}\text { Duration and } \\
\text { number of tasks }\end{array} \\
\text { Behaviour categries }\end{array}$}} & \multirow{2}{*}{\multicolumn{4}{|c|}{$\begin{array}{c}\text { Session } 1 \\
\text { 47'25" for } 7 \text { tasks }\end{array}$}} & \multicolumn{4}{|c|}{ Session 2} & \multicolumn{4}{|c|}{ Session 3} \\
\hline & & & & & & & 29'75" & r 8 tasks & & & $50^{\prime} 25 " \mathrm{f}$ & 10 task & \\
\hline & & \multirow{2}{*}{$\begin{array}{c}\mathrm{AB} \\
\%\end{array}$} & \multirow{2}{*}{$\begin{array}{c}\text { TTB } \\
\%\end{array}$} & \multirow{2}{*}{$\begin{array}{l}\text { EB } \\
\%\end{array}$} & \multirow{2}{*}{$\begin{array}{l}\text { DB } \\
\%\end{array}$} & \multirow{2}{*}{$\begin{array}{c}\mathrm{AB} \\
\%\end{array}$} & \multirow{2}{*}{$\begin{array}{c}\text { TTB } \\
\%\end{array}$} & \multirow{2}{*}{$\begin{array}{c}\mathrm{EB} \\
\%\end{array}$} & \multirow{2}{*}{$\begin{array}{c}\mathrm{DB} \\
\%\end{array}$} & \multirow{2}{*}{$\begin{array}{c}\mathrm{AB} \\
\%\end{array}$} & \multirow{2}{*}{$\begin{array}{c}\text { TTB } \\
\%\end{array}$} & \multirow{2}{*}{$\begin{array}{l}\text { EB } \\
\%\end{array}$} & \multirow{2}{*}{$\begin{array}{l}\text { DB } \\
\%\end{array}$} \\
\hline Students & Levels & & & & & & & & & & & & \\
\hline F14 & Strong & 62.43 & 2.64 & 33.86 & 1.06 & 61.34 & 0.84 & 21.85 & 15.97 & 54.73 & 12.93 & 19.90 & 12.44 \\
\hline F21 & Strong & 74.60 & 5.29 & 17.99 & 2.12 & 63.02 & 8.40 & 21.01 & 7.56 & 68.16 & 4.48 & 13.93 & 13.43 \\
\hline \multicolumn{2}{|c|}{$\begin{array}{l}\text { Averages of strong } \\
\text { students }\end{array}$} & 68.51 & 3.96 & 25.88 & 1.59 & 62.18 & 4.62 & 21.43 & 11.76 & 61.44 & 8.70 & 16.91 & 12.93 \\
\hline $\mathrm{f} 2$ & Weak & 69.84 & 0.53 & 20.10 & 9.52 & 64.70 & 2.52 & 18.49 & 14.28 & 63.68 & 6.96 & 16.91 & 12.44 \\
\hline f7 & Weak & 34.39 & 7.41 & 21.16 & 37.04 & 25.21 & 5.04 & 21.01 & 48.74 & 25.37 & 0.50 & 43.78 & 30.35 \\
\hline \multicolumn{2}{|c|}{$\begin{array}{l}\text { Averages of weak } \\
\text { students }\end{array}$} & 52.11 & 3.97 & 20.63 & 23.28 & 44.95 & 3.78 & 19.75 & 31.51 & 44.52 & 3.73 & 30.34 & 21.39 \\
\hline \multicolumn{2}{|c|}{$\begin{array}{l}\text { Average of the four } \\
\text { students }\end{array}$} & 60.31 & 3.97 & 23.28 & 12.43 & 53.57 & 4.20 & 20.59 & 21.64 & 52.98 & 6.22 & 23.63 & 17.16 \\
\hline
\end{tabular}

derestimated, because the teaching is adapted to a class segment, the other segments being marginalized. So every teacher leads his class with regard to a reference group (Crahay, 1989). The course is generally carried out for a group of "average" or "median" students. Usually the fastest students, those who finish before the other having a high school position and the slowest students those who are behind the advance of knowledge having a low position are penalized.

Student engagement depends also on the nature of the situations prescribed for the class. We have highlighted a lack of differentiated learning situations, even though the institution has sufficient specific equipment (crash mats, bar springboard) susceptible to create real workshops. We interpret these findings by making the hypothesis that the teacher has no teaching resources to develop learning situations differentiated in terms of arrangement of the environment and in terms of definition of success criteria.

The low expertise of the teacher, specialist of tennis, does not allow her either to manage in the joint action the gymnastic learning of her students. These difficulties of conception and management of the didactic situations determine a management class that does not take into account the different school positions of students. Consequently, this has an impact on the degree of cooperation of students in the proposed tasks.

We find what was highlighted by several studies about the importance of teachers' expertise in the didactic management or about the determining role of practical epistemology of the physical education teacher in the evolutionary dynamics of the didactic processes (Amade-Escot, 2013; Elandoulsi, 2011).

Our results confirm those of several authors before us in the field of the ecology of physical education (Brunelle, Drouin, Godbout, \& Tousignant, 1988; Florence, Brunelle, \& Carlier, 1998; Placek, 1983; Tousignant, 1985; Siedentop, 1994) who show that there is a link between the way a teacher leads his class and the forms of cooperation of students.

\section{Conclusion}

Students play on different modalities of engagement to develop social relationships, to develop recreational activities, or to reduce the request of tasks to avoid costs of learning. Our research shows that according to their school position, students do not engage in the same way in the proposed tasks: "strong" students are considered to be more active than the "weak" students.

However, to go beyond these observations, we ask ourselves what are the effects of these modalities of engagement on the teaching-learning process? Indeed, the relation of student engagement towards teaching contents is not enough worked in researches in the teaching of physical education. In other words, students' actions are not sufficiently defined in the literature allowing understanding the ways in which students contribute to the advancement of knowledge in the classroom.

The issue of student participation in the didactic process was the object of few researches even if precursory works (Amade-Escot \& Venturini, 2009; Venturini \& Amade-Escot, 2009) showed that there were tracks of 
deepening to explore in terms of research.

\section{References}

Altet, M., Bressoux, P., Bru, M., \& Leconte-Lambert, C. (1996). Exploratory Study of Teaching Practices in the Classroom of CE2. Les Dossiers d'Éducation et Formations, 70.

Amade-Escot, C. (2013). The Practical Epistemology of Teachers and Research on Intervention. Perspectives for Future Dialogues. In B. Carnel, \& J. Moniotte (Eds.), Intervention, Research and Teaching Education: What Challenges, What Transformations? (pp. 37-58). Amiens: Amiens Picardie University and ARIS.

Amade-Escot, C., \& Léziart, Y. (1996). Contribution to the Study of the Distribution of Didactic Engineering Proposals from Practitioners. Case Analysis of Voluntary Physical Education Teachers. Rapport Scientifique. Recherche INRP, No. 30506.

Amade-Escot, C., \& Marsenach, J. (1995). Didactics of Physical Education. Grenoble: La Pensée Sauvage.

Amade-Escot, C., \& Venturini, P. (2009). Ecological and "Didactique” Perspectives: How Knowledge Co-Construction Is Grasped through the Concepts of "Learning Environment” and "Didactic Milieu” Which Throw Light on "Students' Productive Disciplinary Engagement”. The AIESEP International Seminar Situated Learning, Reflective Practice \& Knowledge Construction in Physical Education, Besançon, 27-29 May 2009.

Brunelle, J., Drouin, D., Godbout, P., \& Tousignant, M. (1988). The Supervision of the Physical Activity Intervention. Montréal: Gaëtan Morin Editeur.

Carlier, G. (2004). If We Spoke of the Pleasure of Teaching Physical Education. Montpellier: Éditions AFRAPS.

Crahay, M. (1989). Constraints Situation and Teacher-Student Interactions, Is It Possible to Change Their Way of Teaching? Revue Française de Pédagogie, 88, 67-84. http://dx.doi.org/10.3406/rfp.1989.2459

Doyle, W. (1986). Paradigms of Research on Teacher Effectiveness. In M. Crahay, \& D. Lafontaine (Eds.), The Art and Science of Teaching (pp. 435-481). Bruxelles: Labor.

Elandoulsi, S. (2011). The Practical Epistemology of Teachers: Effects of Experience and Expertise in Teaching of the Handstand in Coeducational Classes. Comparative Analysis of Three Physical Education Teachers in Tunisia. Ph.D. Thesis, Le Mirail: University of Toulouse 2.

Florence, J., Brunelle, J., \& Carlier, G. (1998). Enseigner l'Education Physique au Secondaire. Bruxelles: De Boeck.

Leutenegger, F. (2003). Study Didactic Interactions in Math Class: A Methodological Prototype. In A. Danis, M. L. Schubauer-Leoni, \& A. Weil-Barais (Eds.), Interaction, Learning and Development (pp. 559-571). Bulletin de Psychologie, 56, 559-571.

Musard, M., Loquet, M., \& Carlier, G. (2010). Sciences of the Intervention in Physical Education and Sport. Research Findings and Theoretical Foundations. Paris: Aris et Editions de la revue EPS.

Placek, J. H. (1983). Conceptions of Success in Teaching: Busy, Happy and Good? In T. Templin, \& J. Olson (Eds.), Teaching in Physical Education (pp. 46-56). Champaign, IL: Human Kinetics.

Schubauer-Leoni, M. L. (1996). Study Teaching Contract for Students in Difficulty in Math: Educational Issues and/or Psychosocial. In C. Raitsky, \& M. Caillot (Eds.), Beyond Didactics, the Didactic: Debates around Common Concepts (pp. 160-189). Paris and Bruxelles: De Boeck.

Schubauer-Leoni, M. L. (2008). The Construction of the Reference in the Joint Action Teacher-Student. In N. Wallian, M. P. Poggi, \& M. Musard (Eds.), Co-Construct of Knowledge: The Art of Intervention by the APSA (pp. 67-86). Besançon: PUFC.

Siedentop, D. (1994). Learning to Teach Physical Education. Montréal: Gaëtan Morin.

Tousignant, M. (1982). Analysis of the Task Structures in Secondary Physical Education Classes. Ph.D. Thesis, Columbus, $\mathrm{OH}$ : Ohio State University.

Tousignant, M. (1985). The Degree of Cooperation of Students: A Source of Equity for the Teacher Assumptions. La revue québécoise de l'activité physique, 3, 69-74.

Tousignant, M., \& Siedentop, D. (1983). The Analysis of Task Structures in Physical Education. Journal of Teaching in Physical Education, 3, 47-57.

Venturini, P., \& Amade-Escot, C. (2009). Conditions Fostering Productive Disciplinary Engagement during a Regular Physics Lesson in a Depressed Area School. Proceedings of the 13rd Biennial EARLI Conference on Fostering Communities of Learners, Amsterdam, 25-29 August 2009. 